\title{
Influence of plants used in agricultural diversification on the nematode Heterorhabditis amazonensis
}

\section{Influência de plantas utilizadas na diversificação agrícola sobre o nematoide Heterorhabditis amazonensis}

\author{
Natalia Ramos Mertz ${ }^{1 *}$; Fernanda Soares Sales²; Elsa Judith Guevara Agudelo; \\ Alcides Moino Junior ${ }^{4}$
}

\section{Highlights}

Crotalaria spectabilis and C. breviflora do not affect the nematode.

Tagetes erecta causes suppression of the initial nematode population.

Plants and Calosoma granulatum did not interfere with the nematode displacement.

\section{Abstract}

In an agricultural system, to increase natural biological control, plants that attract natural enemies can be grown alongside the main crop. However, the effects of these plants on entomopathogenic nematodes (EPNs), important agents for controlling soil pests, and the action of their conservation are unknown. To assess the impact of these plants on EPNs, two experiments were carried out in a greenhouse. The first measured the effect of Crotalaria spectabilis, Crotalaria breviflora, and Tagetes erecta on the persistence and infectivity of Heterorhabditis amazonensis isolate RSC 5 for 27 days, compared to a control treatment without plants. The second trial evaluated the effect of $C$. breviflora and $T$. erecta on the displacement of the nematode. Additionally, the influence of predator Calosoma granulatum in this system was evaluated. The plants did not influence nematode behaviour in terms of persistence, infectivity, or displacement. However, C. spectabilis allowed the most significant persistence of nematodes in the substrate for a short time, and $T$. erecta caused the fastest suppression of the initial population of infectives juvenile. In the second experiment, neither the predator nor the plants affected the nematode's ability to move in the soil within 5 days. These results show that prior knowledge in agricultural diversification can help to control pests by inundative application of EPNs.

Key words: Conservative biological control. Conservation. Entomopathogenic nematodes inundative control. Persistence.

1 Post Doctoral Researcher, Laboratory of Biological Control, Universidade Tecnológica Federal do Paraná, UTFPR, Dois Vizinhos, PR, Brazil. E-mail: nataliamertz@gmail.com

2 Student of the Doctoral Course of the Postgraduate Program in Entomology, Universidade Federal de Lavras, UFLA, Lavras, MG, Brazil. E-mail: fernandass87@hotmail.com

${ }^{3}$ Ph.D. Researcher, Research Center La Libertad, Corporación Colombiana de Investigación Agropecuaria, AGROSAVIA, Villavicencio, Meta, Colômbia. E-mail: eguevara@agrosavia.co

${ }^{4}$ Prof. Dr. of Postgraduate Program in Entomology, UFLA, Lavras, MG, Brazil. E-mail: alcmoino@ufla.br

* Author for correspondence

Received: Nov. 06, 2021 - Approved: Aug. 27, 2021 


\section{Resumo}

Em um sistema agrícola, a fim de aumentar o controle biológico natural, plantas que atraem inimigos naturais podem ser cultivadas junto à cultura principal. Porém, os efeitos destas plantas sobre nematoidesentomopatogênicos (NEPs), importante agentes de controle de pragas de solo, e sua ação na conservação destes, são desconhecidos. Com o objetivo de avaliar o efeito de algumas destas plantas sobre NEPs, foram montados dois experimentos em casa-de-vegetação. O primeiro observou o efeito das plantas Crotalaria spectabilis, Crotalaria breviflora e Tagetes erecta sobre a persistência e infectividade de Heterorhabditis amazonensis isolado RSC 5 durante 27 dias, comparadas a um tratamento-controle sem plantas. Já o segundo experimento avaliou o efeito de C. breviflora e $T$. erecta, com a presença ou não do adulto do predador Calosoma granulatum no deslocamento do nematoide. Os resultados indicaram que as plantas não influenciaram na persistência dos nematoides em longo prazo nem na infectividade e no deslocamento de $H$. amazonensis. Porém, a planta $C$. spectabilis possibilitou a maior persistência de nematoides no substrato em curto prazo, e T. erecta causou a supressão mais rápida da população inicial de Jls. No segundo experimento observou-se que nem a presença do predador e das plantas afetou a capacidade de deslocamento do nematoide no solo no período de 5 dias. Estes resultados mostram que o conhecimento prévio das plantas a serem utilizadas na diversificação agrícola pode auxiliar no controle inundativo de pragas por NEPs.

Palavras-chave: Controle biológico conservativo. Controle inundativo. Conservação. Nematoides entomopatogênicos. Persistência.

\section{Introduction}

Entomopathogenic nematodes (EPNs) of theSteinernematidaeand Heterorhabditidae families are obligate parasites and natural enemies of several insects of economic importance (Lewis \& Clarke, 2012). The life cycle of these EPNs is similar, with a single free-living resistant stage called an infective juvenile (IJ). These nematodes search for hosts and infect them, penetrating through natural openings or the cuticle. The IJs carry symbiotic bacteria (Xenorhabdus or Photorhabdus spp.) that is released into the host's hemocoel, which dies of sepsis after 24 to 72 hours of infection. Inside the host, nematodes feed, develop, mate, and reproduce, and this cycle is repeated until the food source is exhausted and a new generation of IJs is formed that will migrate to the soil and seek new hosts (Poinar \& Grewal, 2012).
Features such as easy application, compatibility with other control methods, and a wide range of hosts have caused EPNs to be marketed in several countries for short-term inundative or augmentative biological control programs (Campos-Herrera, El-Borai, Martín, \& Duncan, 2016; Hodson, Siegel, \& Lewis, 2012; Koppenhöfer, Shapiro-llan, \& Hitpold, 2020; Mahmoud, 2016). These same features make EPNs ideal for conservative strategies of long-term biological control, which are more economical and sustainable (Stuart, Barbercheck, \& Grewal, 2015). Changes in the agricultural environment that increase biodiversity become more attractive and /or favourable to natural enemies, thus reducing the negative impact of herbivores on plants of economic interest (Araj, Shields, \& Wratten, 2019; Quispe, Mazón, \& Rodríguez-Berrío, 2017). 
For efficient conservation of natural enemies, it is necessary to identify which type of biodiversity is needed to maintain or increase biological control (Stuart et al., 2015). The plants used for increasing environmental heterogeneity may directly or indirectly affect the EPNs. The presence of roots can interfere with the search for insect hosts (Ennis, Dillon, \& Griffin, 2010). The maintenance of soil moisture and temperature by plants can generate a microclimate favourable to EPNs (Campos-Herrera et al., 2016). Secondary compounds released by the roots canalter host susceptibility and post-infection IJ production (Gassmann, Stock, Tabashnik, \& Singer, 2010; Hazir et al., 2016). Moreover, these compounds can be attractive, repellent (Jagodič, Ipavec, Trdan, \& Laznik, 2017; Turlings, Hiltpold, \& Rasmann, 2012), or toxic to EPNs (Santhi et al., 2019). Moreover, agricultural biodiversity also increases the diversity and insect availability that can serve as alternative hosts to the key pests (Helmberger, Shields, \& Wickings, 2017) or as vehicles for the displacement of nematodes in the soil (Mertz, Agudelo, Sales, Rohde, \& Moino, 2014).

Thus, this work aimed to evaluate the direct effect of plants used in the diversification of the agricultural environment on the persistence and infectivity of the entomopathogenic nematode Heterorhabditis amazonensis. By adding a predator (Calosoma granulatum, Coleoptera: Carabidae) to this system, the objective was to evaluate possible changes in the displacement of the nematode resulting from the increase in the system's biodiversity.

\section{Materials and Methods}

The experiments were conducted in a greenhouse and laboratory. The greenhouse was of the automatic type, with a cooling system that used evaporative air cooling by a porous medium exhaust. The insects used in the experiments were taken from creations kept in the Laboratory of Microbial Control, the Federal University of Lavras, Minas Gerais, Brazil.

\section{Entomopathogenic nematode production}

The nematode used in the experiments was the native Amazonian species $H$. amazonensis isolate RSC 5, produced by the in vivo method, adapted from Woodring and Kaya (1988), in caterpillars of Galleria mellonella (Linnaeus, 1758) (Lepidoptera: Pyralidae). These were reared according to the methodology described by Dutky, Thompson and Cantwe (1964) using an artificial diet modified by Parra (1998). The viable IJs were counted and stored for a maximum of five days at $16 \pm 1^{\circ} \mathrm{C}$ in a climatic chamber until use in the experiment.

\section{Calosoma granulatum cultivation}

Cultivation conditions were adapted from the methodology proposed by Pasini (1995). Glass bottles (1.3 L, $12 \mathrm{~cm}$ in diameter, and $17 \mathrm{~cm}$ in height), externally wrapped in black plastic, filled up to $1 / 3$ of the volume with Plantmax ${ }^{\circledR}$ commercial artificial substrate, sterilised, and moistened, were used for the maintenance of adult $C$. granulatum. These were fed daily with a piece of banana of the 
variety 'Terra' (Musa paradisiaca, Musaceae), and water was offered in pieces of moistened cotton. When mated, the pairs were fed daily with two caterpillars of Spodoptera frugiperda (Lepidoptera: Noctuidae). Eggs were transferred to plastic containers filled with the same artificial substrate mentioned above. They were kept in a climate chamber at $27 \pm 1^{\circ} \mathrm{C}$, with a photoperiod of 14 hours until the emergence of larvae, which were individualised in plastic containers containing substrate and artificially fed daily with caterpillars of $S$. frugiperda or larvae of Tenebrio molitor L. (Coleoptera: Tenebrionidae) obtained from artificial laboratory conditions.

\section{Plant cultivation}

The plants used in the experiments were Tagetes erecta L. (Astraceae), Crotalaria breviflora L., and Crotalaria spectabilis Roth (Fabaceae), and seedlings were grown in a commercial substrate for planting (Plantmax ${ }^{\circledR}$ ) from commercially-obtained seeds. The seedlings were transferred to plastic vases with a capacity of $2 \mathrm{~L}$, with one seedling per vase filled with $1 \mathrm{~kg}$ of the substrate (soil, sand, and organic fertiliser, in the proportion of $2: 1: 1)$. The pots were kept in a greenhouse at a temperature of $29 \pm 4^{\circ} \mathrm{C}$ and humidity of around $80 \%$. Irrigation was performed twice a day.

\section{Persistence and infectivity experiment}

Seedlings $(15 \mathrm{~cm}$ tall, about 25 days after emergence) were transferred to plastic pots (one seedling per pot) and additionally assembled pots like the others (with the same dimensions and the same amount of substrate, as mentioned in the previous section) but kept without plants. All pots, with or without plants, were placed in a greenhouse and watered daily.

The experiment consisted of 40 pots with $T$. erecta, C. breviflora, and C. spectabilis plants (plants in the flowering stage at 70 days after emergence and about $40 \mathrm{~cm}$ in length) and 40 pots without plants. Each plant species was considered a treatment, and pots without plants were considered the control treatment. Under the substrate in each pot, after watering, a $30 \mathrm{ml}$ distilled water suspension containing 15,000 IJs of nematode $H$. amazonensis was applied homogeneously. Then, the vases were covered and wrapped with a piece of voile-type fabric, the ends of which were tied to protect the substrate from any arthropods that could inhabit the soil and keep the plant's stem free. Plants were watered twice a day by wetting the fabric.

Insect-trap methodology was used to assess infectivity. The percentage of dead insects in the trap was used to monitor changes in nematode infectivity over time (Hass, Griffin, \& Downes, 1999). To assess persistence, the Baermann funnel extraction methodology was used (Baermann, 1917). This methodology made it possible to extract viable nematodes and quantify them since it depends on the movement of EPNs and the action of gravity.

At $3,11,19$, and 27 days after suspension application, ten pots of each treatment and control were separated, and the plant was discarded when present. The substrate was carefully separated and homogenised to separate two aliquots of 150 $\mathrm{mL}$. One aliquot was transferred to a plastic pot with a lid $(10 \times 5 \times 5 \mathrm{~cm})$, where three $G$. mellonella caterpillars were buried as trap 
insects for the nematode. The pots were kept in the laboratory for five days. Subsequently, the caterpillars were removed from the substrate, and the dead ones were dissected to confirm nematode presence.

The other aliquot of the substrate was used for the extraction of nematodes using a Baermann funnel. Glass funnels $(200 \mathrm{~mL}$ capacity) containing an aluminium mesh at the bottom (asa supportfor the sample) and a piece of malleable silicone rubber pipe connected to its stem, closed with a Mohr clamp, were used. The substrate aliquot was placed under a paper towel, positioned at the bottom of the funnel on the aluminium mesh, and the sample was covered with distilled water. After 24 hours, the Mohr clamp was opened, freeing the passage of the suspension and allowing its collection in a Becker-type flask. After 24 hours of decanting the extracted solutions, the extra water was discarded, standardising a volume of $10 \mathrm{~mL}$ for all extracted samples. The entire process was carried out in an acclimatised room at $26 \pm 2^{\circ} \mathrm{C}$. Ten aliquots of $10 \mu \mathrm{L}$ of the suspension of each sample were inoculated in ten wells of a microtiter plate. The IJs present in each well were quantified under a stereoscopic microscope. Thus, the number of IJs in $1 \mathrm{~mL}$ of the suspension was determined.

Each treatment and control had ten repetitions evaluated on four consecutive dates, with an interval of eight days between them. The pots were arranged randomly on benches in the greenhouse, and the experimental design was completely randomised. The greenhouse was kept at a temperature of $29 \pm 4^{\circ} \mathrm{C}$ and humidity of about $80 \%$. Irrigation was carried out directly onto the soil (about $300 \mathrm{~mL}$ of water) twice a day.

\section{Displacement experiment}

The displacement experiment evaluated the effect of $T$. erecta and $C$. breviflora plants and the ground predator C. granulatum on the displacement of the nematode towards a host. Before the plants entered the flowering stage (about 70 days after sowing), one of each species was transferred to the centre of plastic pots ( 40 $\mathrm{cm}$ long, $20 \mathrm{~cm}$ wide, and $20 \mathrm{~cm}$ deep), and the substrate to which they were planted was distributed at the bottom of this new pot. On top of the substrate, $4 \mathrm{~L}$ of soil (red latosol) was added to fill the pot to $12 \mathrm{~cm}$. The plants were maintained under these conditions until they started to bloom. This experiment also included pots without plants, which were considered the control treatment, that were set up in the same way as the others. In these, $2 \mathrm{~L}$ of the substrate (same mixture used in pots with plants) was added, and $4 \mathrm{~L}$ of soil (red latossol) were spread on the bottom of the pot.

Styrofoam screens (mesh with a $1 \mathrm{~mm}$ opening) were used to assemble envelopes $(7 \times 7 \mathrm{~cm})$. Ten G. mellonella caterpillars (3 $\mathrm{cm}$ long) were placed in each envelope, and then, it was closed with paper clips. At $10 \mathrm{~cm}$ away from the plant stem and $10 \mathrm{~cm}$ from the end, a trench was made where the envelope containing the caterpillars was buried vertically. On the opposite side, also $10 \mathrm{~cm}$ away from the plant's stem and $10 \mathrm{~cm}$ from the end of the pot, a small hole was made, $3-5 \mathrm{~cm}$ deep, where a $30 \mathrm{~mL}$ suspension containing $20,000 \mathrm{IJs}$ of the nematode $H$. amazonensis was applied.

In 15 of the 30 pots of each treatment (both plantspeciesand control), a C. granulatum adult ( \pm 40 days of age) was released to freely move about the vessel. Half of the pots in each 
treatment and control had a beetle, and the other half did not. A $5 \mathrm{~mm}$ thick slice of banana (variety Terra) and water-soaked cotton in a plastic cup were placed randomly in the pot to feed the predator.

Thus, each plant species in the presence or absence of an adult predator was considered a treatment, and the control was considered the pot without a plant with the presence or absence of the insect. Evaluations were performed five days after IJ application and consisted of removing envelopes containing G. mellonella larvae. The dead nematodes were dissected and observed under a stereoscopic microscope to confirm nematode mortality. The confirmed mortality of each replicate was counted.

Plants were watered carefully, twice a day, using a small amount of water (about 100 $\mathrm{mL}$ ) to avoid soil drench. The temperature in the greenhouse was $29 \pm 4^{\circ} \mathrm{C}$, and the humidity was approximately $80 \%$. The pots were arranged randomly on the benches, and the experiment was in a completely randomised design.

\section{Data analysis}

Data were tested for normality by the Shapiro-Wilk test. Those obtained in the persistence and infectivity experiments were submitted to the non-parametric KruskalWallis analysis $(P \leq 0.05)$, and the treatments were compared to each other by the SimesHochberg test. The data obtained in the displacement experiment were paired and compared to each other by the Wilcoxon test $(P \leq 0.05)$ using Action Stat software.

\section{Result and Discussion}

The EPNs infected and killed G. mellonella larvae (Figure 1) and were detected using Baermann funnel extraction (Figure 2) until 27 days after inoculation. The proportion of infected caterpillars and the number of extracted nematodes decreased throughout the evaluations, indicating a reduction in nematode survival over time in all treatments (Figures 1 and 2).

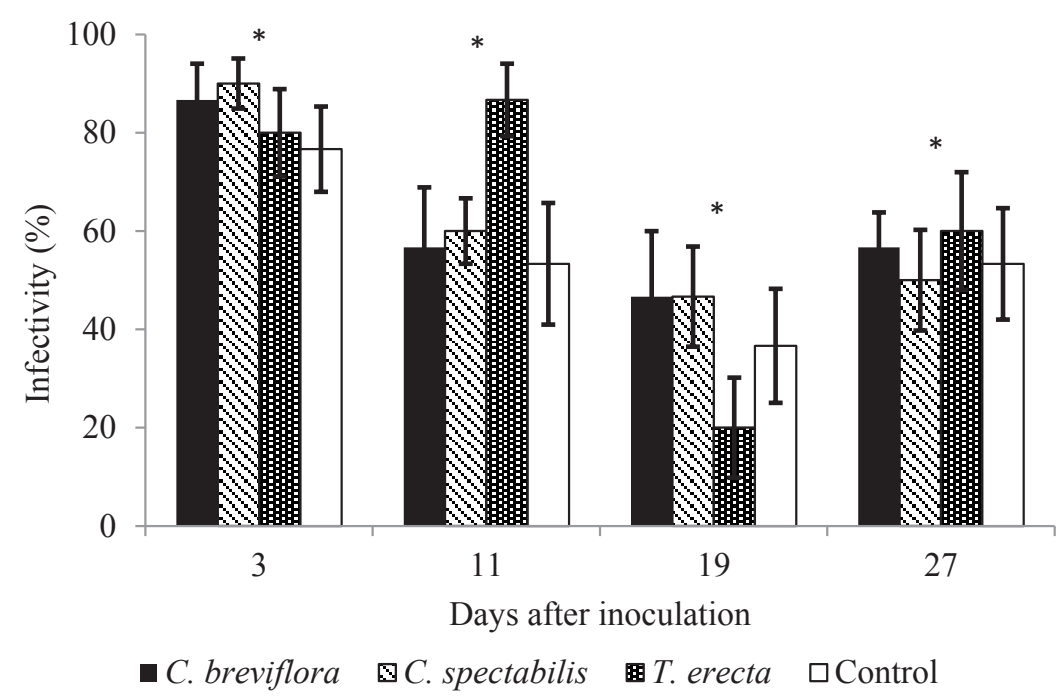

Figure 1. Infectivity of Heterorhabditis amazonensis (mean mortality of Galleria mellonella caterpillars) in the control (substrate only), Crotalaria breviflora, Crotalaria spectabilis, and Tagetes erecta treatments, after $3,11,19$, and 27 days of inoculation in a greenhouse experiment $\left(29 \pm 4^{\circ} \mathrm{C}\right.$, $80 \%$ relative humidity). *non-significant difference $(P \leq 0.05)$. 


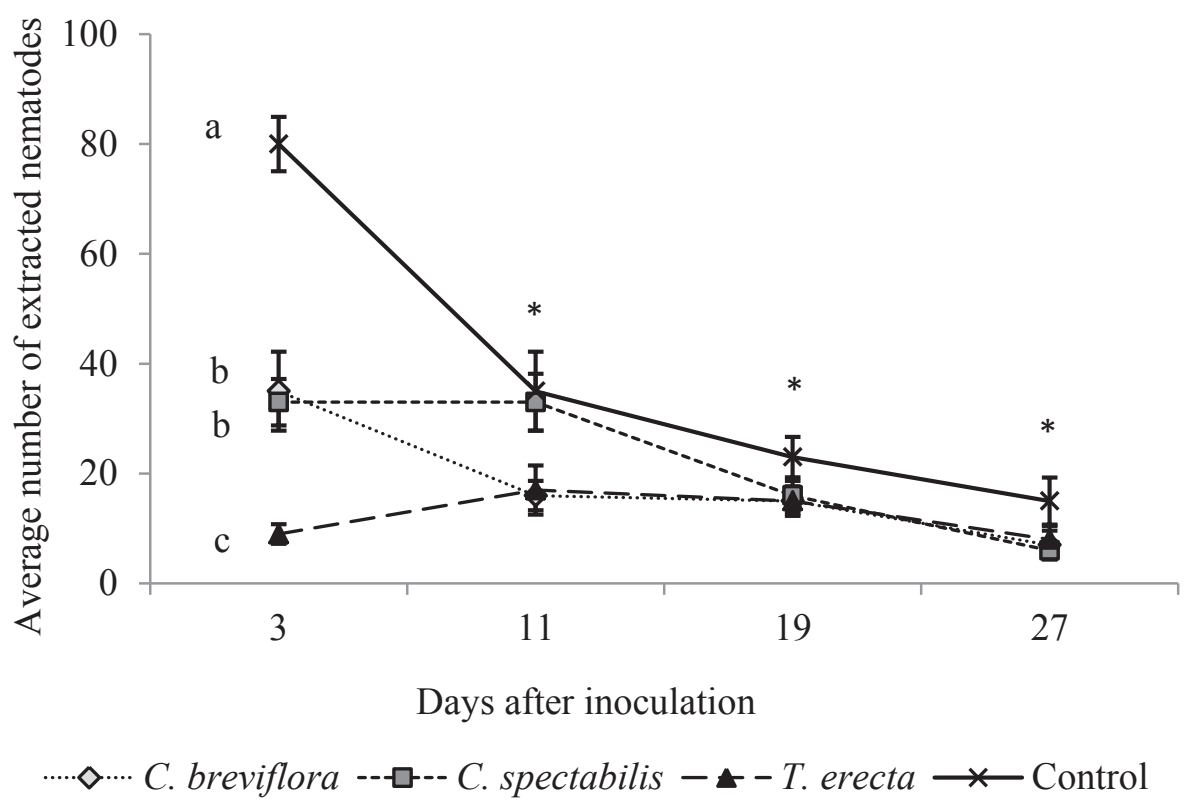

Figure 2. Persistence of Heterorhabditis amazonensis nematodes extracted via Baermann funnel from the control (substrate only), Crotalaria breviflora, Crotalaria spectabilis, and Tagetes erecta treatments in a greenhouse experiment. Different letters next to symbols indicate significant differences between the means on the same evaluation date (Kruskal-Wallis). *non-significant difference $(P \leq 0.05)$.

Using the insect-trap methodology (Figure 1), after three days of inoculation, the mean infectivity between treatments was $83 \%$, and at 27 days after inoculation, it was 55\%. The Kruskal-Wallis test $(P \leq 0.05)$ showed no significant difference between the treatments in any of the assessments.

The persistence of IJs for 27 days, causing mortality of more than half of the trap insects, indicates its high resistance to the high temperatures of the greenhouse (average of $29^{\circ} \mathrm{C}$, with peaks of $33^{\circ} \mathrm{C}$ ). The decrease observed over time was probably related to the decline in the nematode population. Calabuche-Gómez et al. (2019) observed that, among the abiotic factors, temperature most negatively affects $H$. amazonensis over time, with temperatures equal to and above $25^{\circ} \mathrm{C}$, drastically reducing nematode viability and infectivity after seven days of exposure in the laboratory.

The lowest average mortality of $G$. mellonella larvae was observed 19 days after inoculation, with $38 \%$ dead insects (Figure 1). This low mean value was mainly due to the $T$. erecta treatment, which in this evaluation, had the lowest mortality among all observations. This plant demonstrated high variation in mortality over time.

Regarding the quantification of nematodes via Baermann funnel extraction, there was a significant difference between treatments only three days after inoculation (Figure 2). In this evaluation, the largest number of nematodes was found in the control treatment (pot without plants), with twice as many nematodes as in $C$. breviflora and $C$. spectabilis (Figure 2). The least nematodes 
were accounted for in the treatment with $T$. erecta, about four times less than others. In the other evaluations, there was a reduction in the number of nematodes in all treatments, with no significant difference between them.

The large population reduction observed in the control treatment between 3 and 11 days after inoculation may be related to the effect of high temperature (CalabucheGómez et al., 2019). The competition of EPNs with other microorganisms may have been another factor. When counting under a microscope, a great diversity of nematodes and other organisms were observed in the control treatment compared to the other treatments (observational data, not quantified).

Extraction also indicated that the control treatment and $\mathrm{C}$. breviflora caused the most considerable reduction in population between the 3rd and 11 th day after inoculation, when the population dropped by half between the two evaluations. In the C. spectabilis treatment, the most significant reduction occurred between the 11th and 19th day after inoculation since the number of nematodes was stable between the 3rd and 11th. The $T$. erecta treatment was the only one that did not follow the same pattern as that of other plants because the number of nematodes in it was low on the 3rd and 27th day after inoculation (about ten nematodes).

Plants of the Crotalaria genus are widely used as cover crops or in partnership with other cultures having a large biomass capacity and biological nitrogen fixation (by the symbiosis that they perform with bacteria of the Rhizobium genus) (Berriel, Monza, \& Perdomo, 2020). Furthermore, they attract a great diversity of insects and natural enemies (Supriyadi, Wijayanti, Arniputri, Puspitarini, \& Dwiyatno, 2019; Tavares et al., 2010). They are also able to control phytonematodes, benefiting antagonists and producing secondary compounds that are toxic or inhibitory to them, such as the monocrotaline pyrrolizidine alkaloids, which reduce the hatching of juveniles and motility (Galbieri, Fuzattoii, Ciaii, Welteri, \& Fanan, 2011; Osei, Gowen, Pembroke, Brandenburg, \& Jordan, 2010; Ratnadass, Fernandes, Avelino, \& Habib, 2012; Santana et al., 2012). However, despite the literature demonstrating its nematicidal effect, the results presented here show that $C$. spectabilis maintained the highest and most stable number of viable EPNs on the 3rd day after inoculation, in relation to the other plants evaluated (Figure 2), with no effect on their infectivity (Figure 1). Therefore, C. spectabilis can be safely used as a green manure to increase environmental heterogeneity, favouring natural enemies, in addition to the control of phytonematodes, without causing significant adverse effects on the population of the nematode $H$. amazonensis when flooding is applied.

Although C. breviflora did not affect infectivity (Figure 1), it reduced the EPN population faster than C. spectabilis. In both, pyrrolizidine alkaloids were found. These are secondary metabolites that affect various parameters of phytopathogenic nematodes in vitro. However, these effects vary between plant and nematode species (Gardiano et al., 2010; Thoden \& Boppré, 2010).

$T$. erecta caused a rapid population reduction of nematodes in an inundative application to the soil. Plants of this genus also control phytopathogenic nematodes when used as a cover crop or in rotation with other crops. In field experiments, Adekunle (2011) observed that the incorporation of $T$. erecta and $C$. juncea plants caused a reduction in phytonematode damage in legumes infected with Meloidogyne incognita. Plants of the 
genus Tagetes act as non-host plants to phytonematodes, benefit antagonists, and are a source of nematicidal extracts (Adekunle, 2011).

One of the main nematicide compounds produced by $T$. erecta is $\alpha$-terthienyl (Hooks, Wang, Ploeg, \& Mcsorley, 2010). However, little is known about the effect of this compound on EPNs. Kanagy and Kaya (1996) conducted studies with the EPN Steinernema glaseri and demonstrated that high concentrations of $\alpha$-tertienil reduce the number of IJs that infect hosts. However, it is still unclear how the plant releases this compound and how its toxic effect is activated since EPNs do not have better or worse performance in the presence of Tagetes roots. This indicates that perhaps the natural concentrations of this compound suppress phytonematodes but not EPNs (Grubišić, Uroić, Ivošević, \& Grdiša, 2018; Hooks et al., 2010; Kanagy \& Kaya, 1996).
The results presented here show that $H$. amazonensis was initially harmed by the action of $T$. erecta in the persistence experiment (Figure 2). In addition, the infectivity results (Figure 1) showed that, despite not having differed, the infectivity pattern varied over time, not following the same pattern as the other plants.

\section{Displacement experiment}

There was no difference in G. mellonella larvae mortality between treatments by the Wilcoxon test $(P \leq 0.05)$. This indicated that a similar number of nematodes managed to move $20 \mathrm{~cm}$ away towards the host in five days, regardless of the presence of the plant or the C. granulatum adult. Thus, caterpillar mortality was 30 to $40 \%$ in these treatments (Figure 3).

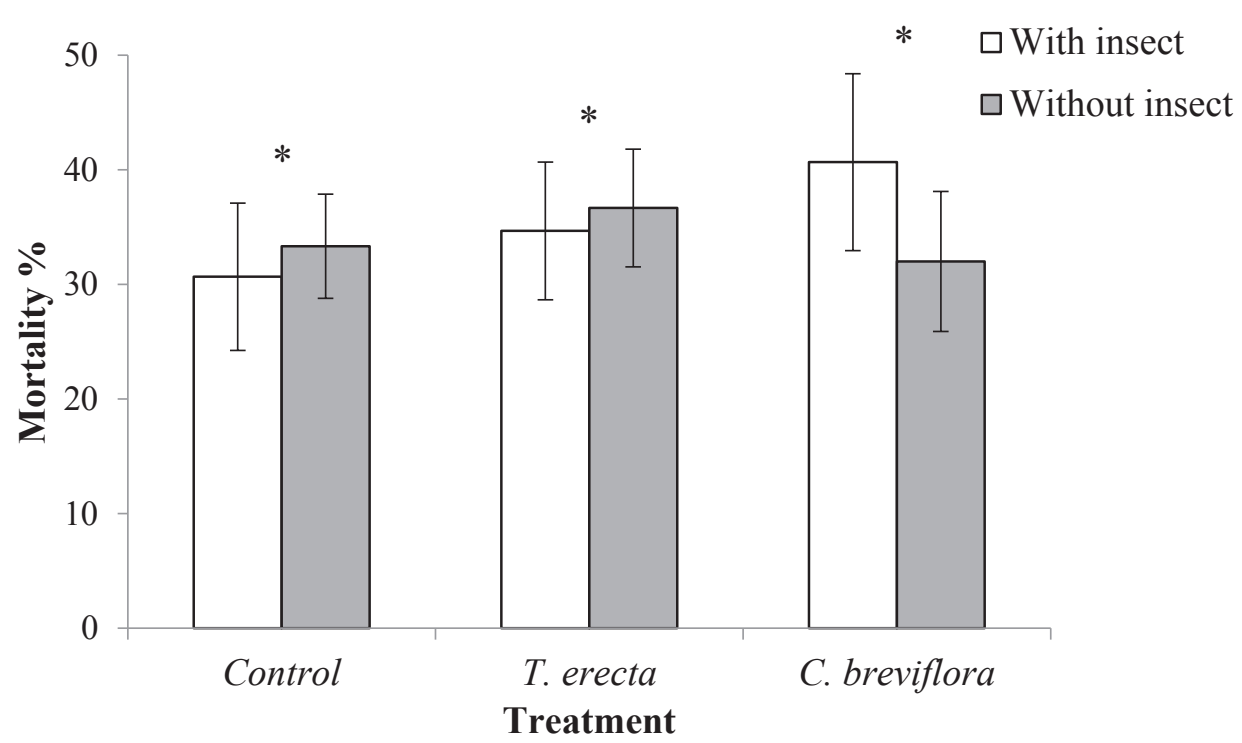

Figure 3. Mortality percentage of Galleria mellonella caterpillars due to the action of the nematode Heterorhabditis amazonensis applied in the substrate (control) or where the species Crotalaria breviflora or Tagetes erecta were placed and an adult of $C$. granulatum was released or not. Nematodes (20000 IJs) applied $20 \mathrm{~cm}$ away from the host, five days before evaluation, in a greenhouse experiment $\left(29 \pm 4^{\circ} \mathrm{C}, 80 \% \mathrm{RH}\right)$. ${ }^{*}$ non-significant difference $(\mathrm{P} \leq 0.05)$. 
Both larvae and adults of the $C$. granulatum predator are considered good agents for phoretic dispersion of the nematode in laboratory tests (Mertz et al., 2014). However, due to the testing distance $(20 \mathrm{~cm})$ and the time available to cover this distance (5 days), it can be deduced that the distance and time were sufficient for the nematodes to overcome any factor imposed by the plants that could limit its movement toward the host. In the experiment carried out by Andaló et al. (2012), in six days, the nematode $H$. amazonensis caused $80 \%$ mortality of $G$. mellonella caterpillars that were $40 \mathrm{~cm}$ away from the inoculation point in a sand column, indicating that this nematode has great horizontal displacement capacity in search of the host.

Plants used to beneficially increase the diversity of the agricultural system may have effects on some EPN parameters. The conservative biological control of EPNs is only possible after identifying the environmental factors that affect these nematodes. While the direct effects of soil physical properties, such as water potential, porosity, and temperature, have been studied in detail on EPNs, little attention is given to understanding the importance of biological interactions and how they vary in different habitats (CamposHerrera, Stuart, El-Borai, Gutierrez, \& Duncan, 2010).

\section{Conclusions}

Plants can interfere in the number of newly inoculated nematodes in the soil, without affecting their infectivity or displacement towards a host. Cultivating plants such as $C$. spectabilis together with those of economic interest, which in the case of the adoption of inundative biological control with nematodes, will keep the newly inoculated population viable in the soil for a period, increased control efficiency. In addition, $T$. erecta had an immediate antagonistic effect on the persistence of $H$. amazonensis without affecting its infectivity.

\section{References}

Adekunle, O. K. (2011). Amendment of soil with African marigold and sunn hemp for management of Meloidogyne incognita in selected legumes. Crop Protection, 30(11), 1392-1395. doi: 10.1016/j.cropro. 2011.07.007

Andaló, V., Santos, V., Moreira, G. F., Moreira, C., Freire, M., \& Moino, A. (2012). Movement of Heterorhabditis amazonensis and Steinernema arenarium in search of corn fallarmywormlarvaeinartificial conditions. Scientia Agricola, 69(3), 226-230. doi: 10.1590/S0103-90162012000300008

Araj, S., Shields, M. W., \& Wratten, S. D. (2019). Weed floral resources and commonly used insectary plants to increase the efficacy of a whitefly parasitoid. BioControl, 64(5), 553-561. doi: 10.1007/ s10526-019-09957-x

Baermann, G. (1917). Eine einfache methode zur auffindung von Ancylostomum (Nematoden) larven in erdproben. Geneeskunding Tijdschrift voor Nederlandsch-Indië, 57, 131-137.

Berriel, V., Monza, J., \& Perdomo, C. H. (2020). Cover crop selection by jointly optimizing biomass productivity, biological nitrogen fixation, and transpiration efficiency: application to two Crotalaria species. Agronomy, 10(8), 1116. doi: 10.3390/ agronomy 10081116 
Calabuche-Gómez, G., Regalado, R. E., Perera, D. G., Cabrera, I. M., Soler, D. M., \& Hernández, M. G. R. (2019). Efecto de factores abióticos sobre la viabilidad e infectividade de Heterorhabditis amazonensis Andaló et al. cepa HC1. Revista de Protección Vegetal, 34(3), 1-9. Retrieved form http://scielo.sld.cu/ scielo. php?script $=$ sci_arttext $\&$ pid $=$ S1010$27522019000300004 \&$ lng $=$ es\&nrm=iso

Campos-Herrera, R., El-Borai, F. E., Martín, J. A. R., \& Duncan, L. W. (2016). Entomopathogenic nematode food web assemblages in Florida natural areas. Soil Biology and Biochemistry, 93, 105-114. doi: 10.1016/j.soilbio.2015.10.022

Campos-Herrera, R., Stuart, R. J., El-Borai, F., Gutierrez, C., \& Duncan, L. (2010). Entomopathogenic nematode ecology and biological control in Florida citrus orchards. In A. Ciancio, \& K. G. Mukerji (Eds.), Integrated management of arthropod pests and insect borne diseases (pp. 101130). Dordrecht: Springer.

Dutky, S. R., Thompson, J. V., \& Cantwe, G. E. (1964). A technique for the mass propagation of the DD-136 nematode. Journal of Insect Pathology, 6(4), 417422.

Ennis, D. E., Dillon, A. B., \& Griffin, C. T. (2010). Simulated roots and host feeding enhance infection of subterranean insect by the entomopathogenic nematode Steinernema carpocapsae. Journal of Invertebrate Pathology, 103(2), 140-143. doi: 10.1016/j.jip.2009.11.004

Galbieri, R., Fuzattoii, M. G., Ciaii, E., Welteri, A. M., \& Fanan, S. (2011). Desempenho de genótipos de algodoeiro na presença ou não de rotação de cultura com Crotalaria spectabilis, em área infestada com Meloidogyne incognita. Tropical Plant Pathology, 36(5), 303-307. doi: 10.1590/ S1982-56762011000500005

Gardiano, C. G., Dallemole-Giaretta, R., Lopes, E. A., Zooca, R. J. F., Ferraz, S., \& Freitas, L. G. (2010). Atividade nematicide de extratos de sementes de espécies de Crotalaria sobre Meloidogyne javanica. Revista Trópica - Ciências Agrárias e Biológicas, 4(1), 1-5. doi: 10.0000/rtcab. v4i1.76

Gassmann, A. J., Stock, P., Tabashnik, B. E., \& Singer, M. S. (2010). Tritrophic effects of host plants on a herbivore-pathogen interaction. Annals of the Entomological Society of America, 103(3), 371-378. doi: 10.1603/AN09130

Grubišić, D., Uroić, G., Ivošević, A., \& Grdiša, M. (2018). Nematode control by the use of antagonistic plants. Agriculturae Conspectus Scientificus, 83(4), 269-275. Retrieved from https://acs.agr.hr/acs/ index.php/acs/article/view/1518

Hass, B., Griffin, C. T., \& Downes, M. J. (1999). Persistence of Heterorhabditis infective juveniles in soil: comparison of extraction and infectivity measurements. Journal of Nematologists, 31(4), 508-516. Retrieved from https://www.ncbi.nlm.nih.gov/pmc/ articles/PMC2620384/

Hazir, S., Shapiro-Ilan, D. I., Hazir, C., Leite, L. G., Cakmak, I., \& Olson, D. (2016). Multifaceted effects of host plants on entomopathogenic nematodes. Journal of Invertebrate Pathology, 135, 53-59. doi: 10.1016/j.jip.2016.02.004 
Helmberger, M. S., Shields, E. J., \& Wickings, K. G. (2017). Ecology of belowground biological control: Entomopathogenic nematode interactions with soil biota. Applied Soil Ecology, 121, 201-213. doi: 10.1016/j.apsoil.2017.10.013

Hodson, A. K., Siegel, J. P., \& Lewis, E. E. (2012). Ecological influence of the entomopathogenic nematode, Steinernema carpocapsae, on pistachio orchard soil arthropods. Pedobiologia, 55(1), 51-58. doi: 10.1016/j. pedobi.2011.10.005

Hooks, C. R. R., Wang, K. H.,Ploeg, A., \&McSorley, R. (2010). Using marigold (Tagetes spp.) as a cover crop to protect crops from plant-parasitic nematodes. Applied Soil Ecology: A Section of Agriculture, Ecosystems \& Environment, 46(3), 307320. doi: 10.1016/j.apsoil.2010.09.005

Jagodič, A., Ipavec, N., Trdan, S., \& Laznik, Z. (2017). Attraction behaviors: Are synthetic volatiles, typically emitted by insectdamaged Brassica nigra roots, navigation signals for entomopathogenic nematodes (Steinernema and Heterorhabditis)? Biocontrol, 62(4), 515-524. doi: 10.1007/ s10526-017-9796-x

Kanagy,J.M.N.,\&Kaya,H.K.(1996).The possible role of marigold roots and $\alpha$-terthienyl in mediating host-finding by Steinernematid nematodes. Nematologica, 42(2), 220231. doi: $10.1163 / 004325996 \times 00066$

Koppenhöfer, A. M., Shapiro-Ilan, D. I., \& Hitpold, I. (2020). Entomopathogenic nematodes in sustainable food production. Frontiers in Sustainable Food Systems, 4, 1-14. doi: 10.3389/fsufs. 2020.00125
Lewis, E. E., \& Clarke, D. J. (2012). Nematode parasites and entomopathogens. In F.Vega, \& H. Kaya (Eds.), Insect pathology (pp. 395-424). Cambrige: Academic Press.

Mahmoud, M. F. (2016). Biology and use of entomopathogenic nematodes in insect pests biocontrol, a generic view. Cercetari Agronomice in Moldava, 49(4), 85-105. doi: 10.1515/cerce-2016-0039

Mertz, N. R., Agudelo, E. J. G., Sales, F. S., Rohde, C., \& Moino, A., Jr. (2014). Phoretic dispersal of the entomopathogenic nematode Heterorhabditis amazonensis by the beetle Calosoma granulatum. Phytoparasitica, 42(2), 179-187. doi: 10. 1007/s12600-013-0349-2

Osei, K., Gowen, S. R., Pembroke, B., Brandenburg, R. L., \& Jordan, D. L. (2010). Potential of leguminous cover crops in management of a mixed population of root-knot nematodes (Meloidogyne spp.). Journal of Nematology, 42(3), 173-178. Retrieved from https://www.ncbi.nlm.nih. gov/pmc/articles/PMC3380490/

Parra, J. R. P. (1998). Raising insects for studies of pathogens. In S. B. Alves (Eds.), Microbial control of insects (pp. 10151037). Piracicaba: FEALQ.

Pasini, A. (1995). Biologia e técnica de criação do predador Calosoma granulatum Perty, 1830 (Coleoptera: Carabidae) em Anticarsia gemmatalis Hübner, 1818 (Lepidoptera: Noctuidae), lagarta-da-soja. Tese de doutorado, Escola Superior de Agricultura "Luiz de Queiróz", Piracicaba, SP, Brasil.

Poinar, G. O., Jr., \& Grewal, P. S. (2012). History of entomopathogenic nematology. 
Journal of Nematology, 44(2), 153-161. Retrieved from https://www.ncbi.nlm.nih. gov/pmc/articles/PMC3578475/

Quispe, R., Mazón, M., \& Rodríguez-Berrío, A. (2017). Do refuge plants favour natural pest control in maize crops? Insects, 8(3), 71. doi: 10.3390/insects8030071

Ratnadass, A., Fernandes, P., Avelino, J., \& Habib, R. (2012). Plant species diversity for sustainable management of crop pests and diseases in agroecosystems: a review. Agronomy for Sustainable Development, 32(1), 273-303. doi: 10.1007/s13593-01 $1-0022-4$

Santana, S. M., Dias-Arieira, C. R., Biela, F., Cunha, T. P. L., Chiamolera, F. M., Puerari, H. H., \& Fontana, L. F. (2012). Manejo de Pratylenchus zeae por plantas antagonistas, em solos de áreas de cultivo de cana-de-açúcar. Nematropica, 42(1), 63-71. Retrieved from https://journals. flvc.org/nematropica/article /view/79583

Santhi, V. S., Salame, L., Muklada, H., Azaizeh, H., Haj-Zaroubi, M., Awwad, S., Landau, S. Y., Glazer, I. (2019). Toxicity of phenolic compounds to entomopathogenic nematodes: a case study with Heterorhabditis bacteriophora exposed to lentisk (Pistacia lentiscus) extracts and their chemical components. Journal of Invertebrate Pathology, 160, 43-53. doi: 10.1016/j.jip.2018.12.003

Stuart, R. J., Barbercheck, M. E., \& Grewal, P. S. (2015). Entomopathogenic nematodes in the soil environment: distribution interactions and the influence of biotic and abiotic factors. In: R. Campos-Herrera (Ed.), Nematode pathogenesis of insects as other pests (pp. 97-137). Dordrecht: Springer.
Supriyadi, R., Wijayanti, R., Arniputri, B., Puspitarini, N., \& Dwiyatno, M. H. (2019). The effect of Crotalaria juncea plant in coffee ecosystem to the diversity and abundance of predators and parasitoids insects. IOP Conference Series: Earth and Environmental Science, 250(1), 1-6. doi: 10.1088/1755-1315/250/1/012018

Tavares, W. S., Cruz, W. S. I., Silva, R. B., Figueiredo, M. L. C., Ramalho, F. S., Serrão, J. E. V., \& Zanuncio, J. C. (2010). Soil organisms associated to the weed suppressant Crotalaria juncea (Fabaceae) and its importance as a refuge for natural enemies. Planta Daninha, 29(3), 473-479. doi: 10.1590/S0100-83 582011000300001

Thoden, T. C., \& Boppré, M. (2010). Plants producing pyrrolizidine alkaloids: Sustainable too nematode management? Nematology, 12(1), 1-24. doi: 10.1163/13 8855409X12549869072248

Turlings, T. C. J., Hiltpold, I., \& Rasmann, S. (2012). The importance of rootproduces volatiles as foraging cues for entomopathogenic nematodes. Plant Soil, 358(1), 51-60. doi: 10.1007/s11104012-1295-3

Woodring, J. L., \& Kaya, H. K. (1988). Steinernematid and heterorhabditid nematodes: handbook of biology and techniques. Fayetteville: Arkansas Agricultural Experimental Station. 
